\title{
Antinociceptive Effect of Lodenafil Carbonate in Rodent Models of Inflammatory Pain and Spinal Nerve Ligation-Induced Neuropathic Pain
}

This article was published in the following Dove Press journal: Journal of Pain Research

\author{
Marcio Carneiro Vieira $\mathbb{D}^{1,2}$ \\ Fernanda Bezerra de Mello \\ Monte ${ }^{3}$ \\ Bruno Eduardo Dematte ${ }^{3}$ \\ Tadeu Lima Montagnoli (D) $^{3}$ \\ Guilherme Carneiro \\ Montes $^{3}$ \\ Jaqueline Soares da Silva $\mathbb{D}^{3}$ \\ Rosalia Mendez-Otero (iD ${ }^{4}$ \\ Margarete Manhães Trachez $\mathbb{D D}^{3}$ \\ Roberto Takashi Sudo 1,3 \\ Gisele Zapata-Sudo 1,3
}

'Programa de Pós-graduação em Ciências Cirúrgicas, Universidade Federal do Rio de Janeiro, Rio de Janeiro, 2194I-902,

Brazil; ${ }^{2}$ Hospital Universitário

Clementino Fraga Filho, Universidade

Federal do Rio de Janeiro, Rio de Janeiro, 2194I-902, Brazil; ${ }^{3}$ Programa de Pesquisa em Desenvolvimento de Fármacos, Instituto de Ciências Biomédicas, Universidade Federal do Rio de Janeiro, Rio de Janeiro, 21941-902, Brazil; ${ }^{4}$ Instituto de Biofísica Carlos Chagas Filho, Universidade Federal do Rio de Janeiro, Rio De Janeiro, 2194I-902, Brazil
Introduction: New therapeutic alternatives for pain relief include the use of phosphodiesterase-5 (PDE5) inhibitors, which could prevent the transmission of painful stimuli by neuron hyperpolarization via nitric oxide (NO)/cyclic 3',5'-guanosine monophosphate (cGMP) pathway. The present work investigated the antinociceptive activity of a new PDE5 inhibitor, lodenafil carbonate, in inflammatory and neuropathic pain models.

Methods and Results: Although no effect was detected on neurogenic phase of formalin test in mice, oral administration of lodenafil carbonate dose-dependently reduced reactivity in the inflammatory phase $(200.6 \pm 39.1$ to $81.9 \pm 18.8 \mathrm{~s}$ at $10 \mu \mathrm{mol} / \mathrm{kg}, \mathrm{p}=0.0172)$ and this effect was totally blocked by NO synthase inhibitor, L-N $\omega$-nitroarginine methyl ester (L-NAME). Lodenafil carbonate $(10 \mu \mathrm{mol} / \mathrm{kg}$ p.o.) significantly reduced nociceptive response as demonstrated by increased paw withdrawal latency to thermal stimulus (from $6.8 \pm 0.7$ to $10.6 \pm 1.3 \mathrm{~s}, \mathrm{p}=0.0006$ ) and paw withdrawal threshold to compressive force (from $188.0 \pm 14.0$ to $252.5 \pm 5.3 \mathrm{~g}, \mathrm{p}<0.0001$ ) in carrageenan-induced paw inflammation model. In a spinal nerve ligation-induced neuropathic pain, oral lodenafil carbonate (10 $\mu \mathrm{mol} / \mathrm{kg}$ ) also reversed thermal hyperalgesia and mechanical allodynia by increasing paw withdrawal latency from $17.9 \pm 1.5$ to $22.8 \pm 1.9 \mathrm{~s}(\mathrm{p}=0.0062)$ and paw withdrawal threshold from $26.0 \pm 2.8$ to $41.4 \pm 2.9 \mathrm{~g}(\mathrm{p}=0.0196)$. These effects were reinforced by the reduced GFAP $(3.4 \pm 0.5$ to $1.4 \pm 0.3 \%, \mathrm{p}=0.0253)$ and TNF-alpha $(1.1 \pm 0.1$ to $0.4 \pm 0.1 \%, \mathrm{p}=$ 0.0111 ) stained area densities as detected by immunofluorescence in ipsilateral dorsal horns. Conclusion: Lodenafil carbonate demonstrates important analgesic activity by promoting presynaptic hyperpolarization and preventing neuroplastic changes, which may perpetuate chronic pain, thus representing a potential treatment for neuropathic pain.

Keywords: neuropathic pain, inflammatory pain, phosphodiesterase 5 inhibitor, lodenafil carbonate, spinal cord, GFAP

\section{Introduction}

Phosphodiesterases (PDE) are hydrolytic enzymes mainly responsible for the degradation of cyclic 3'5'-adenosine monophosphate (cAMP) and cyclic 3'5'guanosine monophosphate (cGMP), interfering with cellular events. ${ }^{1}$ Both cAMP and cGMP are mediators of various pathways involving the release of hormones, neurotransmitters and cytokines. ${ }^{2}$ Increased concentrations of these cyclic nucleotides also result in phosphorylation of a variety of regulatory proteins, including transcription factors and ion channels and regulation of numerous physiological processes such as immune response, smooth muscle contraction, apoptosis and cell
Correspondence: Gisele Zapata-Sudo Instituto de Ciências Biomédicas, Centro de Ciências da Saúde, Universidade Federal do Rio de Janeiro, Rio de Janeiro, 2194|-902, Brazil

Tel +55 21 39386505

Email gsudo@icb.ufrj.br 
growth. Therefore, PDE inhibitors are clinically relevant due to their vasodilatory, anti-inflammatory, antidepressant and antithrombotic activities. ${ }^{3}$

The PDE5 isoform exhibits high selectivity towards cGMP and its localization is mainly in smooth muscle, heart and lungs. ${ }^{4,5}$ Enzyme inhibition results in cytosolic cGMP accumulation which activates protein kinase $\mathrm{G}$ (PKG), leading to reduced intracellular calcium levels and smooth muscle relaxation. ${ }^{1}$ These effects led to an initial interest in PDE5 as therapeutic target, directing the clinical use of PDE5-selective inhibitors in erectile dysfunction and pulmonary hypertension. ${ }^{6,7}$

The antinociceptive action of PDE5 inhibitors is already known and inhibition of either guanylyl cyclase (GC), PKG or $\mathrm{K}^{+}$channels abolishes this effect, ${ }^{8-10}$ as shown with sildenafil, vardenafil and tadalafil. ${ }^{9,11,12}$ Lodenafil carbonate is a new dimeric PDE5 inhibitor structurally related to sildenafil and bearing a carbonate bridge. Although its actions on the cardiovascular system were already studied, ${ }^{13-15}$ the antinociceptive activity of lodenafil carbonate has not yet been investigated, and its study in models of inflammatory and neuropathic pain is of great interest for the development of new therapeutic strategies to alleviate chronic pain.

\section{Experimental Section Materials and Reagents}

Lodenafil carbonate, ketamine and heparin were gently donated by Cristália Produtos Químicos e Farmacêuticos Ltda (Itapira, SP, Brazil). Vehicle for oral administration consisted of a mixture of benzyl alcohol, polysorbate 80 , disodium EDTA, hydroxyethylcellulose and water in a proprietary formula of Cristália Produtos Químicos e Farmacêuticos Ltda (Itapira, SP, Brazil). Antibodies rabbit anti-glial fibrillary acid protein (GFAP, ab7260) and mouse anti-tumor necrosis factor (TNF)- $\alpha$ (ab1793) were purchased from Abcam (Cambridge, MA, USA) and secondary fluorescent antibodies goat anti-rabbit-Alexa 488 $\mathrm{F}(\mathrm{ab})_{2}$ (A11070) and goat anti-mouse-Alexa $546 \mathrm{~F}(\mathrm{ab})_{2}$ (A11018) were purchased from Invitrogen (Carlsbad, CA, USA). TO-PRO-3 iodide was purchased from Thermo Scientific (Waltham, MA, USA). Vectashield was purchased from Vector Laboratories (Burlingame, CA, USA). Tissue-Tek optimal cutting temperature (OCT) compound was purchased from Sakura Finetek (Torrance, CA, USA). All other reagents used were obtained from Sigma-Aldrich (St Louis, MO, USA).

\section{Animals}

The experimental protocols were approved by the Ethics Committee of Animal Use and Experimentation of Federal University of Rio de Janeiro (licenses 033/18 and 056/19). Animals were obtained and kept in the animal facility of Graduate Program in Pharmacology and Medicinal Chemistry (Rio de Janeiro, RJ, Brazil) and maintained in accordance with Brazilian Guide of Production, Maintenance and Utilization of Animals for Teaching or Scientific Research Activities (1st edition, 2016) approved by the National Council for Control of Animal Experimentation. Male Swiss mice (25-30 g) and Wistar rats (220-280 g) were freely fed with standard chow and water and housed under controlled conditions $\left(22-24^{\circ} \mathrm{C}\right.$; $12 / 12 \mathrm{~h}$ dark/light cycle) in cages containing 4 animals each. Animals were accommodated in the experimental room for at least 30 minutes before the initiation of behavioral tests.

\section{Formalin Test}

Peripheral analgesia was assessed using the formalin test, ${ }^{16-18}$ which consisted in the subcutaneous injection of $20 \mu \mathrm{L}$ of $2.5 \%$ formalin in the right hind paw of male Swiss mice. A biphasic behavioral nociceptive response was recorded as reactivity (time spent biting or licking) during a first neurogenic phase, until 5 min post-injection, and a latter inflammatory phase, 15 to $30 \mathrm{~min}$ postinjection. Vehicle or lodenafil carbonate $(3,10$ and 30 $\mu \mathrm{mol} / \mathrm{kg}$ p.o.) was administered by gavage $30 \mathrm{~min}$ before formalin injection. The contribution of nitric oxide synthase (NOS) to antinociceptive effects was evaluated after pre-treatment with $\mathrm{L}-\mathrm{N}^{\omega}$-nitroarginine methyl ester (L-NAME) a nonselective NOS inhibitor (3 mg/kg, i.p.) $10 \mathrm{~min}$ before lodenafil carbonate administration.

\section{Carrageenan-Induced Inflammatory Pain}

Lodenafil carbonate antinociception on inflammatory pain model was evaluated in carrageenan-induced paw inflammation. ${ }^{18,19}$ Briefly, male Swiss mice (25-30 g) received $20 \mu \mathrm{L}$ of $1 \%$ carrageenan by intraplantar injection in right hind paws. Behavioral responses to mechanical and thermal stimuli were obtained before and after $2.5 \mathrm{~h}$ of carrageenan injection and 30,60,90, 120 and $150 \mathrm{~min}$ after treatment with a single oral dose of either vehicle, acetylsalicylic acid $(1665 \mu \mathrm{mol} / \mathrm{kg})$ or lodenafil carbonate (3, 10 or $30 \mu \mathrm{mol} / \mathrm{kg}$ ) administered by gavage. 
Mechanical nociceptive threshold was determined using a Randall-Selitto analgesymeter (model EFF440, Insight, Ribeirão Preto, SP, Brazil) by imposing a progressive force (expressed in grams) on the injected paw until withdrawal. ${ }^{20}$ Maximal pressure set at $250 \mathrm{~g}$. Thermal nociceptive latency (in seconds) was observed by immersion of injected paw in a $46^{\circ} \mathrm{C}$ water bath until withdrawal was observed (Montes et al, 2016). ${ }^{18}$

\section{Spinal Nerve Ligation}

The neuropathic pain model was induced in male Wistar rats (220 to $260 \mathrm{~g}$ ) by L5 spinal nerve ligation (SNL) under ketamine $(80 \mathrm{mg} / \mathrm{kg}$ i.p. $)$ and xylazine $(15 \mathrm{mg} / \mathrm{kg}$ i. p.) anesthesia. ${ }^{21,22}$ Briefly, after a dorsal midline incision, paraspinal muscles were separated at spinal L4-S2 level and the right L6 transverse process was removed. Then, the right L5 spinal nerve was isolated and tightly ligated with $6-0$ silk suture. Sham-operated rats underwent the same procedure except for nerve ligation.

Seven days after surgery, it was observed reduced threshold for thermal hyperalgesia and mechanical allodynia in ipsilateral hind paws which confirmed the neuropathic pain. It was used a radiant heat source coupled to a plantar analgesymeter (model 33, ITC, Woodland Hills, CA, USA) and a filament (1 mm external diameter) connected to a digital analgesymeter (model EFF301, Insight, Ribeirão Preto, SP, Brazil). ${ }^{19,22}$ Then, animals were randomly divided to receive orally either vehicle or lodenafil carbonate ( 3 or $10 \mu \mathrm{mol} / \mathrm{kg}$ ) by gavage during 14 days. Threshold responses to mechanical and thermal stimuli were analyzed 3, 7, 10 and 14 days after starting treatment.

\section{Immunofluorescence Analysis}

After the last behavioral evaluation, animals were anesthetized with ketamine $(80 \mathrm{mg} / \mathrm{kg}$ i.p.) and xylazine $(15 \mathrm{mg} / \mathrm{kg}$ i.p.), injected with heparin (1000 U/kg i.p.) and briefly perfused with phosphate-buffered saline (PBS) solution followed by $4 \%$ paraformaldehyde solution until complete blood substitution. After laminectomy, spinal cords were cryopreserved in 30\% sucrose solution, frozen in OCT compound and sectioned transversely in craniocaudal direction in $10 \mu \mathrm{m}$ sections in a cryostat (CM1850, Leica, Wetzlar, Germany).

For immunofluorescence staining, spinal cord sections at L5 level (two per animal) were blocked in 10\% normal goat serum in phosphate-buffered saline (PBS) and incubated with primary antibodies to GFAP $(1: 1000)$ or TNF- $\alpha$ (1:100) overnight at $4^{\circ} \mathrm{C}$. Then, after incubating for $60 \mathrm{~min}-$ utes with secondary antibodies (1:1000 in PBS with $0.1 \%$
Triton X-100) and $0.1 \mu \mathrm{g} / \mathrm{mL}$ TO-PRO-3 (as nuclear stain), sections were washed in PBS and mounted in Vectashield. Two additional sections served as negative controls, by omitting primary antibody in overnight incubation. ${ }^{23}$

Digital micrographs were acquired in a confocal microscope (LSM 510, Zeiss, Germany) at 20x magnification on ipsilateral dorsal horns. Images were analyzed using Fiji distribution of ImageJ $2,{ }^{24}$ by selecting stained green or red areas in ipsilateral dorsal horns from the experimental animals. Stained area densities were expressed as the percentual stained area of each picture. ${ }^{23}$

\section{Statistical Analysis}

Data were expressed as mean \pm standard error of the mean (S.E.M.) and analyzed using Prism 6.0 (GraphPad, San Diego, CA, USA). One-way, two-way ANOVA (followed by the Dunnett post hoc test) or Student's $t$-test were used and the difference between groups was considered significant when $p<0.05$.

\section{Results}

\section{Lodenafil Carbonate Attenuates Nociception of Inflammatory but Not Neurogenic Origin in Mice}

Oral administration of PDE-5 inhibitor lodenafil carbonate displayed no antinociceptive effect in the first phase of formalin test, while behavioral responses to nociception were reduced in the second phase (Figure 1). In vehicle-treated mice, the observed reactivities in the neurogenic and inflammatory phases were $54.6 \pm 7.4 \mathrm{~s}$ and $200.6 \pm 39.1$, respectively. In the first phase, lodenafil carbonate was unable to change reactivity time at the doses of $3 \mu \mathrm{mol} / \mathrm{kg}(43.8 \pm$ $10.7 \mathrm{~s}, p=0.7958), 10 \mu \mathrm{mol} / \mathrm{kg}(43.8 \pm 10.7 \mathrm{~s}, p=0.6563)$ or $30 \mu \mathrm{mol} / \mathrm{kg}(52.0 \pm 7.2 \mathrm{~s}, p=0.9915)$, when compared to the vehicle group. In contrast, lodenafil carbonate showed a dose-dependent antinociceptive effect in the inflammatory phase. When compared to vehicle-treated animals, reactivity was not altered by lodenafil carbonate at $3 \mu \mathrm{mol} / \mathrm{kg}(156.8 \pm$ $29.9 \mathrm{~s}, p=0.5729)$ but significantly reduced after oral administration either at $10 \mu \mathrm{mol} / \mathrm{kg}(81.9 \pm 18.8 \mathrm{~s}, p=0.0172)$. Moreover, a further increase in dose from 10 to $30 \mu \mathrm{mol} / \mathrm{kg}$ did not improve the antinociceptive effect observed. Pretreatment with L-NAME ( $3 \mathrm{mg} / \mathrm{kg}$ i.p.) completely abolished the antinociceptive effect of $10 \mu \mathrm{mol} / \mathrm{kg}$ lodenafil carbonate $(223.0 \pm 40.5 \mathrm{~s}, p=0.0070)$ in the inflammatory phase of formalin test. 
$\square$ Vehicle

Lodenafil carbonate $3 \mu \mathrm{mol} / \mathrm{kg}$

Lodenafil carbonate $10 \mu \mathrm{mol} / \mathrm{kg}$

W Lodenafil carbonate $30 \mu \mathrm{mol} / \mathrm{kg}$

$\square$ Lodenafil carbonate $10 \mu \mathrm{mol} / \mathrm{kg}+$ L-NAME

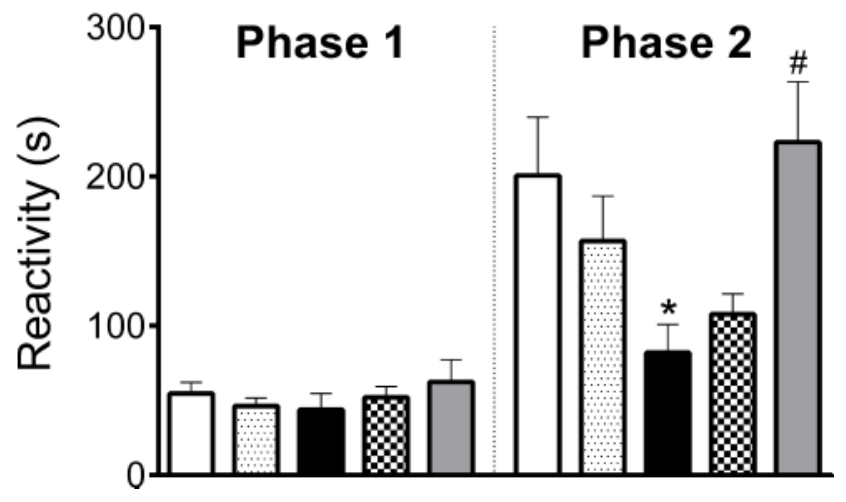

Figure I Oral lodenafil carbonate-induced antinociceptive effect on the biphasic pain response of formalin test. Data represent reactivity time spent licking or biting the formalin-injected paw. Data are expressed as mean \pm S.E.M. $(n=10) .{ }^{*} p<0.05$ compared to vehicle-treated group (one-way ANOVA, Dunnett post hoc test), ${ }^{*} p<0.05 \mathrm{com}$ pared to treatment with $10 \mu \mathrm{mol} / \mathrm{kg}$ lodenafil carbonate (Student's $t$-test).

\section{Lodenafil Carbonate Displays}

\section{Antinociceptive Effects in Mice with}

\section{Carrageenan-Induced Hyperalgesia}

The antinociceptive efficacy of lodenafil carbonate was further investigated in carrageenan-induced inflammatory pain model (Figure 2). Development of thermal hyperalgesia occurred within 2.5 hours after carrageenan injection, as indicated by reduction of paw withdrawal latency to immersion in a heated water bath $(14.2 \pm 0.3$ to $6.8 \pm 0.7 \mathrm{~s}$, $p<0.0001$; Figure 2A). Treatment with lodenafil carbonate resulted in decreased thermal hyperalgesia at all doses tested, in a similar way to acetylsalicylic acid at a clinically relevant dose $(300 \mathrm{mg} / \mathrm{kg})$. After 2.5 hours of oral administration, vehicle-treated animals still presented a paw withdrawal latency of $6.4 \pm 0.5 \mathrm{~s}$, while mice in lodenafil carbonate groups showed longer latencies of $10.7 \pm 1.1(3 \mu \mathrm{mol} / \mathrm{kg}$; $p=0.0003), 10.6 \pm 1.3(10 \mu \mathrm{mol} / \mathrm{kg} ; p=0.0006)$ and $9.0 \pm$ $1.0 \mathrm{~s}(30 \mu \mathrm{mol} / \mathrm{kg} ; p=0.0559)$. Acetylsalicylic acid $(1667$ $\mu \mathrm{mol} / \mathrm{kg}$ ) also increased paw withdrawal latency to $9.7 \pm 0.7$ $\mathrm{s}(p=0.009)$, when compared to the vehicle group.

Likewise, after 2.5 hours of carrageenan injection, a decrease in paw withdrawal threshold to compressive force $(257.0 \pm 1.7$ to $188.0 \pm 14.0 \mathrm{~g}, \mathrm{p}<0.0001)$ indicated the establishment of mechanical hyperalgesia (Figure 2B). Oral administration of lodenafil carbonate also significantly increased the paw withdrawal threshold at all doses tested, indicating a complete reversal of carrageenan-induced mechanical hyperalgesia (Figure 2B). At the end of the test, mice which received vehicle by oral route still showed a reduced withdrawal threshold of $162.0 \pm 7.7 \mathrm{~g}$, while those in acetylsalicylic acid group presented an increase to $226.0 \pm$

\section{- Vehicle \\ - Acetylsalicylic acid $1665 \mu \mathrm{mol} / \mathrm{kg}$}

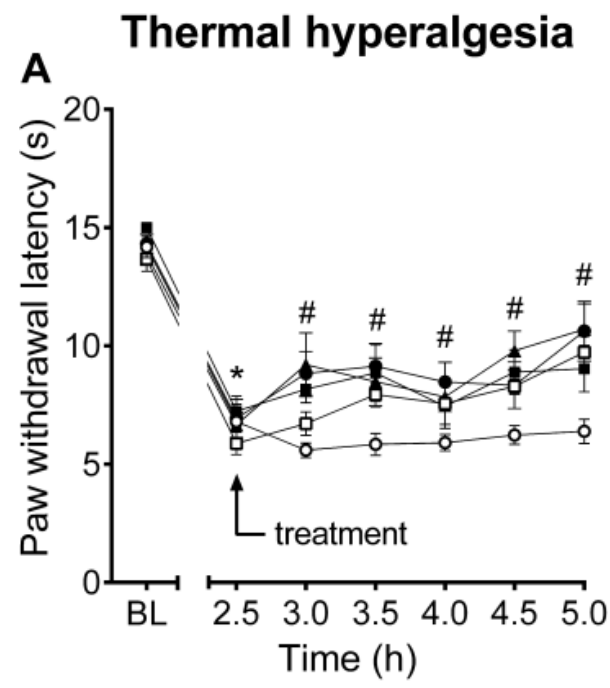

- Lodenafil $3 \mu \mathrm{mol} / \mathrm{kg}$

- Lodenafil $10 \mu \mathrm{mol} / \mathrm{kg}$

Lodenafil $30 \mu \mathrm{mol} / \mathrm{kg}$

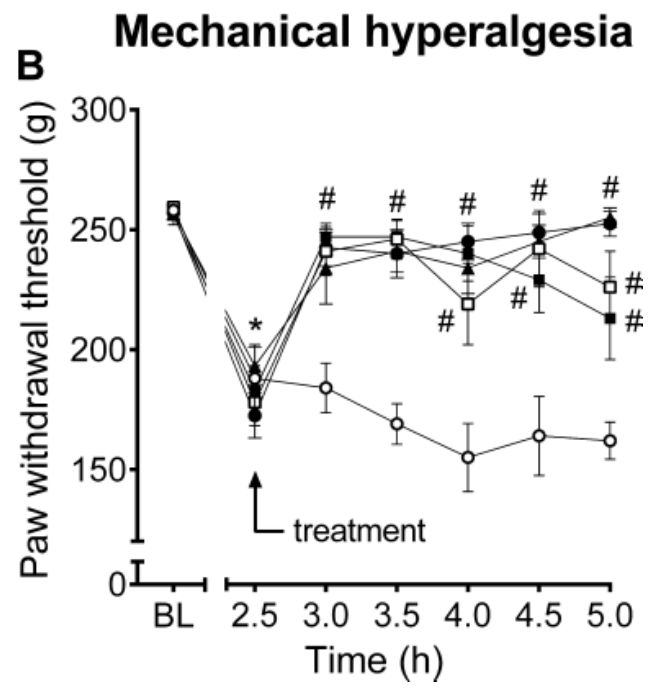

Figure 2 Thermal latencies (A) and mechanical thresholds (B) in the ipsilateral hind paw of mice before and after oral treatment with vehicle, acetylsalicylic acid (I665 $\mu$ mol/ $\mathrm{kg}$ ) or lodenafil carbonate $(3,10,30 \mu \mathrm{mol} / \mathrm{kg})$ in carrageenan-induced paw inflammation model. Data are expressed as mean \pm S.E.M. $(\mathrm{n}=10)$. ${ }^{*} p<0.05 \mathrm{compared}$ to baseline (one-way ANOVA, Dunnett post hoc test); ${ }^{\#} p<0.05$ compared to vehicle-treated group (two-way ANOVA, Dunnett post hoc test). 
$14.9 \mathrm{~g}(p=0.0002)$. Lodenafil carbonate at doses of 3,10 and $30 \mu \mathrm{mol} / \mathrm{kg}$ also elevated the paw withdrawal threshold of carrageenan-injected rats to $255.0 \pm 4.0(p<0.0001), 252.5 \pm$ $5.3(p<0.0001)$ and $213.0 \pm 17.1(p=0.0047)$.

\section{Oral Administration of Lodenafil} Carbonate Produces Antinociception to Mechanical and Thermal Stimuli in a Neuropathic Pain Model in Rats

To evaluate the antinociceptive activity of lodenafil carbonate in a neuropathic pain model, Wistar rats subjected to SNL were treated with either vehicle or lodenafil carbonate at 3 or $10 \mu \mathrm{mol} / \mathrm{kg}$ (Figure 3). Seven days after surgery, SNL animals presented reduced paw withdrawal latency to radiant heat stimulus $(17.9 \pm 1.5 \mathrm{~s} ; \mathrm{p}<0.0001)$ when compared to Sham (26.3 $\pm 0.5 \mathrm{~s})$, indicating thermal hyperalgesia (Figure 3A). During the 14 days of treatment, thermal hyperalgesia was maintained in SNL animals after treatment with either vehicle or oral lodenafil carbonate at $3 \mu \mathrm{mol} / \mathrm{kg}$. However, oral lodenafil carbonate at $10 \mu \mathrm{mol} / \mathrm{kg}$ increased paw withdrawal latency, with a complete reversal of thermal hyperalgesia by 7 days of treatment $(23.6 \pm 1.5 \mathrm{~s} ; p=0.5530$ vs Sham; $p<0.0001$ vs $\mathrm{SNL}+$ vehicle), which lasted until the end of treatment $(22.8 \pm 1.9 \mathrm{~s} ; p=0.7114$ vs Sham; $p=0.0062$ vs $\mathrm{SNL}+$ vehicle).
Additionally, SNL rats also presented mechanical allodynia at 7 days after surgery, as suggested by the reduced paw withdrawal threshold to pressure stimulus $(26.0 \pm 2.8$ g; $p=0.0004$; Figure 3B), when compared to Sham animals $(43.9 \pm 1.3 \mathrm{~g})$. At $3 \mu \mathrm{mol} / \mathrm{kg}$, lodenafil carbonate demonstrated a significant reduction in withdrawal threshold only after 14 days of treatment $(43.3 \pm 1.9 \mathrm{~g}$; $\mathrm{p}=$ 0.7664 vs Sham; $p=0.0147$ vs SNL+vehicle). In contrast, oral administration of lodenafil carbonate at $10 \mu \mathrm{mol} / \mathrm{kg}$ reverted mechanical allodynia after just 3 days of treatment, elevating paw withdrawal threshold to $40.8 \pm 3.6$ $\mathrm{g}(p=0.0007 \mathrm{vs} \mathrm{SNL}+$ vehicle). Moreover, this reduction in withdrawal threshold remained until the last day of treatment $(41.4 \pm 2.9 \mathrm{~s} ; p=0.0196$ vs SNL+vehicle).

\section{Treatment with Lodenafil Carbonate Reduces Spinal Cord Glial Cell Activation and Neuroinflammation in Neuropathic Pain Model in Rats}

In order to further explore the effects of lodenafil carbonate on the cellular changes involved in neuropathic pain chronification, expression of GFAP and TNF- $\alpha$ in ipsilateral dorsal horns was investigated in ipsilateral dorsal horns of SNL rats at L5 level of spinal cord using indirect immunofluorescence (Figure 4A). When compared to the
SNL+Lodenafil carbonate $3 \mu \mathrm{mol} / \mathrm{kg}$

SNL+Lodenafil carbonate $10 \mu \mathrm{mol} / \mathrm{kg}$

\section{B \\ Mechanical allodynia}

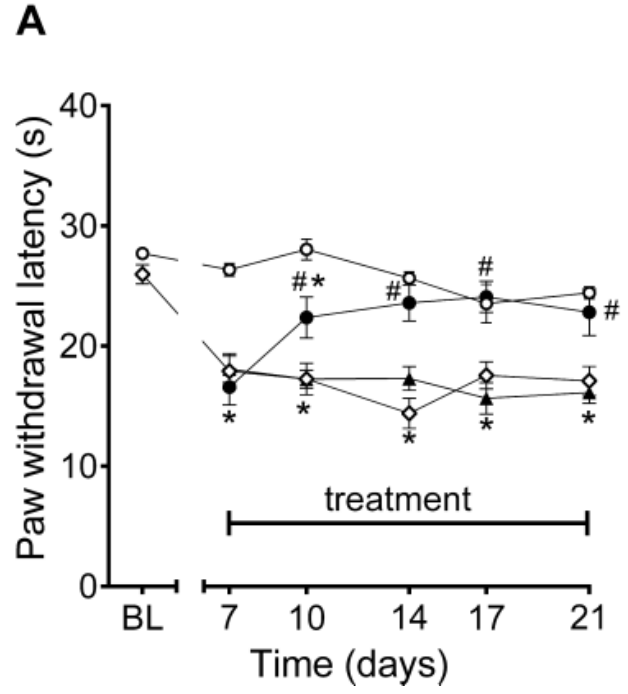

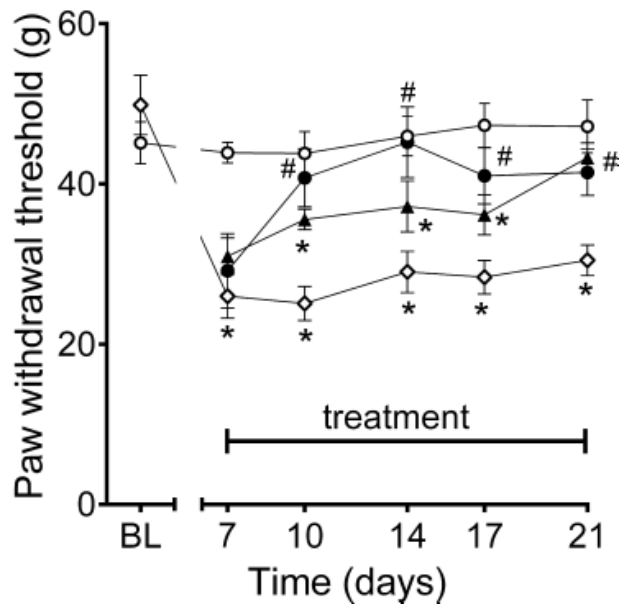

Figure 3 Thermal latencies $(\mathbf{A})$ and mechanical thresholds $(\mathbf{B})$ in the ipsilateral hind paw before and after oral treatment of vehicle or lodenafil carbonate $(3$, I0 $\mu$ mol $/ \mathrm{kg})$ in SNL rats. Data are expressed as mean \pm S.E.M. $(n=6) .{ }^{*} p<0.05$ compared to Sham, ${ }^{\#} p<0.05$ compared to SNL-vehicle group (two-way ANOVA, Dunnett post hoc test). 


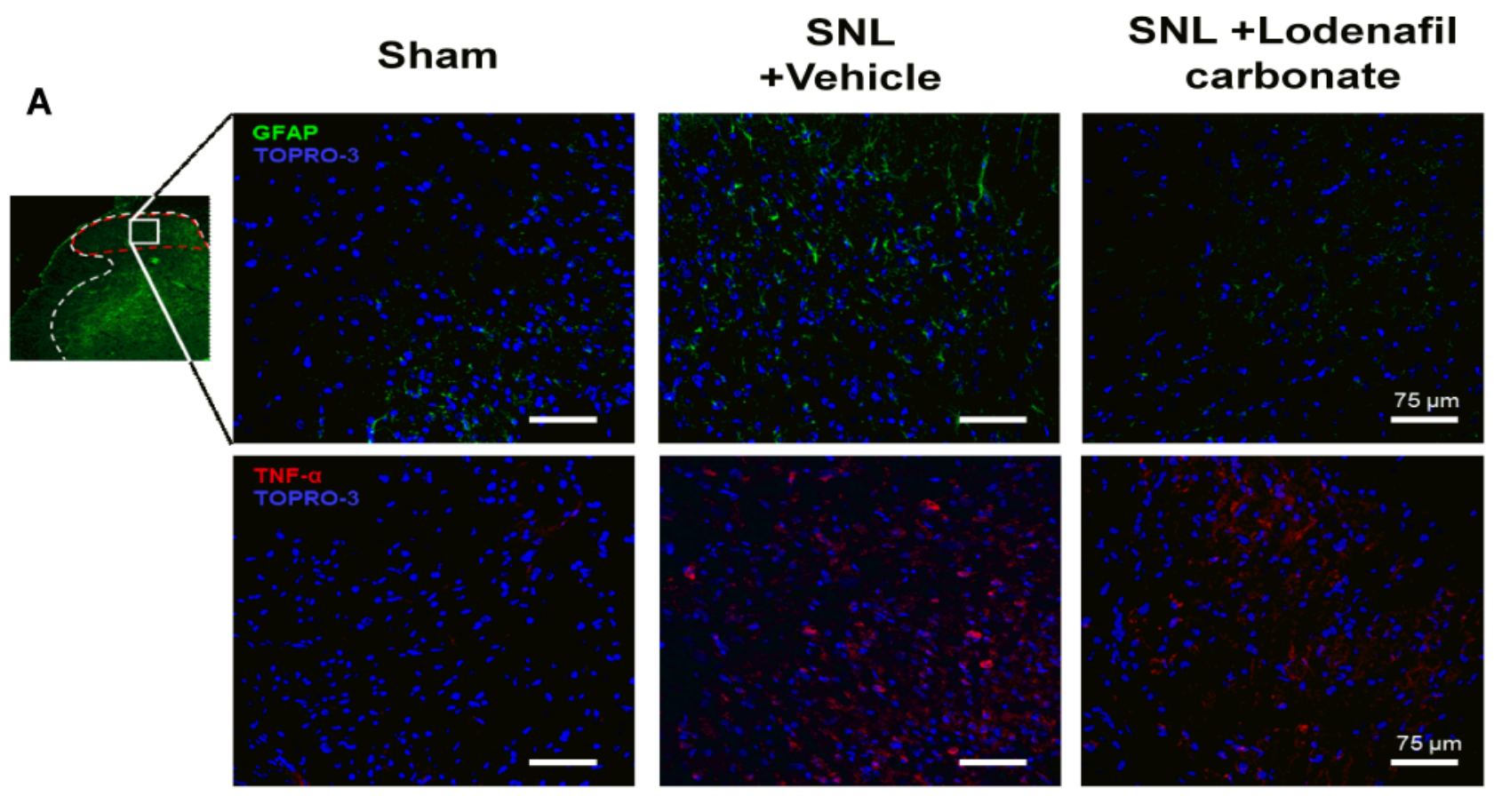

$\square$ Sham 四 SNL+Vehicle

B

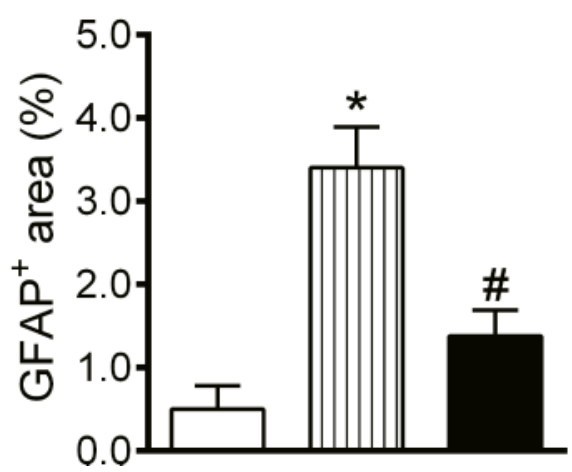

SNL+Lodenafil carbonate $10 \mu \mathrm{mol} / \mathrm{kg}$ C

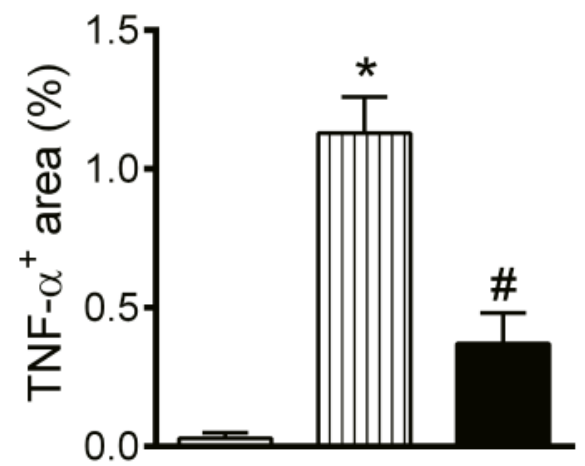

Figure 4 Immunofluorescence analysis of spinal cords of Sham and SNL rats (A). Ipsilateral dorsal horns (insert, red dashed area, $5 \times$ magnification) were analyzed for

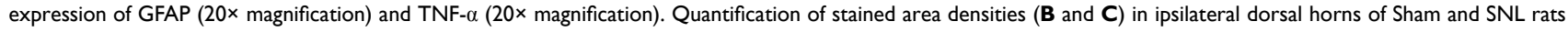
after either treatment with vehicle or lodenafil carbonate $(10 \mu \mathrm{mol} / \mathrm{kg})$. Scale bars represent $75 \mu \mathrm{m}$. Data are expressed as mean \pm S.E.M. $(\mathrm{n}=6)$. ${ }^{*} p<0.05 \mathrm{compared}$ to Sham, ${ }^{\#} p<0.05$ compared to SNL-vehicle group (Student's $t$-test).

Sham group, SNL rats showed an increased staining density of GFAP staining $(0.50 \pm 0.28$ to $3.40 \pm 0.49 \%, p=$ 0.0027 ; Figure 4B), as well as TNF- $\alpha$ staining $(0.03 \pm 0.02$ to $1.13 \pm 0.13 \%, p=0.0004$; Figure $4 \mathrm{C}$ ). Oral treatment with lodenafil carbonate at $10 \mu \mathrm{mol} / \mathrm{kg}$ for 14 days significantly reduced the expression of both GPAF $(1.38 \pm$ $0.31 \%, p=0.0253)$ and TNF- $\alpha(0.37 \pm 0.11 \%, p=0.0111)$ compared to $\mathrm{SNL}+$ vehicle group.

\section{Discussion}

Intracellular cyclic nucleotide is are of great interest because of possible interference in pain given its involvement in the modulation of peripheral and central nervous systems. ${ }^{25-27}$ Although mechanistically poorly understood, the contribution of cGMP to pain and analgesia since it promotes sensitization in central pathways, ${ }^{25,26,28-31}$ while it mediates the antinociceptive effect of peripherally administered drugs, such as morphine, dipyrone, gabapentin and cannabinoids. $^{28,32,33}$

The intracellular concentration of cGMP is controlled by the regulation of GC and PDE enzyme activities. ${ }^{25}$ Among cGMP-selective PDE enzymes, PDE5 is expressed on the nervous system ${ }^{34,35}$ and its influence on cGMP levels may be explored for the development of new analgesic drugs. 
Indeed, local or intraperitoneal administration of PDE5 inhibitors, as sildenafil and vardenafil, causes antinociceptive effects in animal models of pain, ${ }^{9,11,12,36}$ which are mediated by an increase in peripheral cGMP levels. In this study, the potential analgesic effects of an orally active PDE5 inhibitor, lodenafil carbonate, were evaluated in formalin and carrageenan mouse models of inflammatory pain and the SNL rat model of neuropathic pain.

Lodenafil carbonate similarly to sildenafil did not affect the nociceptive behavior on the neurogenic phase of formalin test in mice. This finding indicates a lack of central analgesic action when given by oral route. ${ }^{11,37-39}$ In contrast, lodenafil carbonate reduced the reactivity in the second phase of formalin test, in a dose-dependent manner, as observed with other PDE5 inhibitors, independently of the route of administration. ${ }^{8,12,38-40}$ This effect was totally blocked by L-NAME, a nonselective NOS inhibitor, ${ }^{41}$ which demonstrates the importance of NO to lodenafil carbonatemediated antinociception. ${ }^{38}$ After its synthesis, NO can diffuse through biological membranes and stimulate autocrine or paracrine signaling pathways, such as the production of cGMP by NO-dependent soluble GC. ${ }^{29}$ However, the precise role of $\mathrm{NO}$ in nociceptive transmission modulation in central and peripheral nervous systems is complex and dependent on its location and concentration. Antinociception is generally associated with low NO synthesis by constitutive NOS isoforms, while NO overproduction by inducible NOS often results in hyperalgesia and tissue inflammation. ${ }^{28,29}$ Spinal sensitization may also be promoted by NO through post-translational modification of N-methyl-D-aspartate (NMDA) receptors and increased substance $\mathrm{P}$ release, ${ }^{28,29}$ while interaction with descending inhibitory pathways may contribute to NO-mediated analgesia. ${ }^{42}$

As the peripheral antinociception caused by $\mathrm{NO}$ is mediated by cGMP/PKG/K ${ }^{+}$channels, ${ }^{8,43}$ inhibition of PDE5 represents an alternative for stimulating this pathway while overcoming the limitations in targeted modulation of NO bioavailability. As a result, an increase in cGMP half-life would increase $\mathrm{K}^{+}$channel conductance and lead to nociceptor hyperpolarization, thus potentially decreasing action potential propagation through primary afferents and neurotransmitter release at dorsal horn. ${ }^{29,43}$

In order to investigate the intensity and duration of the antinociceptive effect to different stimuli, thermal and mechanical paw withdrawal thresholds were evaluated after a single oral dose of lodenafil carbonate $(3,10$ or $30 \mu \mathrm{mol} / \mathrm{kg}$ ) in carrageenan-induced hyperalgesia in mice. Groups receiving lodenafil carbonate showed significantly reduced thermal hyperalgesia and displayed total reversal of mechanical hyperalgesia from 30 minutes after treatment until the end of test, which paralleled the effect seen with $300 \mathrm{mg} / \mathrm{kg}(1665 \mu \mathrm{mol} / \mathrm{kg})$ of acetylsalicylic acid. Comparable results were previously described either for sildenafil, vardenafil or tadalafil, ${ }^{9-11}$ and their blockade by L-NAME was also reported, reinforcing the importance of the NO/cGMP pathway for the observed effects.

These findings prompted the study of treatment for 14 days with lodenafil carbonate on the mechanical allodynia and thermal hyperalgesia in a neuropathic pain rat model. Reversal of neuropathic pain behavior was observed after treatment with lodenafil carbonate for 7 days, as indicated by normalization of paw withdrawal latency to radiant heat and paw withdrawal threshold to tactile stimuli. These results are in agreement with the observed after treatment with sildenafil in a neuropathic pain model in rats. ${ }^{44}$

Neuroplastic changes, which mediate central and peripheral sensitization and increase synaptic potentiation in pain circuits are detected in neuropathic pain. ${ }^{45}$ Neuropathic pain is accompanied by glial cell activation and proliferation, characterized by the predominance of microglia and inflammatory cells in an early phase followed by activated astrocytes. $^{23,46-48}$ Although the first phase is related to establishment of neuropathic pain, late inhibition of microglia does not reduce preexisting hyperalgesia, indicating that astrocyte activation may be directly involved in pain chronification $^{49,50}$ Animals submitted to SNL and treated with vehicle showed a 7-fold increase in density of stained area corresponding to GFAP in ipsilateral dorsal horns and oral administration of lodenafil carbonate $(10 \mu \mathrm{mol} / \mathrm{kg}) \mathrm{sig}$ nificantly attenuated staining density of activated astrocytes. As sustained stimulation of nociceptors leads to an increase in GFAP-expressing astroglia in the spinal cord, ${ }^{51}$ this effect may reflect the reduced frequency of action potential transmission to spinal levels by afferent fibers due to lodenafilinduced presynaptic hyperpolarization.

Among the cytokines implicated in neuroplasticity and glial cell activation of dorsal horns, TNF- $\alpha$ seems to play a major role by modulating neuron excitability and synaptic strength in neuropathic pain. Additionally, changing expression of ionotropic glutamate receptors, growth factors and NOS. ${ }^{52}$ In the spinal cord of SNL rats, TNF- $\alpha$ is expressed in neurons, glial and inflammatory cells ${ }^{49}$ and mediates astrocyte and microglial activation and synaptic potentiation in primary sensory neurons. ${ }^{51}$ TNF- $\alpha$ supports the spinal changes involved in the perpetuation of pain condition. Oral administration of lodenafil carbonate $(10 \mu \mathrm{mol} / \mathrm{kg})$ 
lowered approximately $67 \%$ of the 40 -fold increase in TNF- $\alpha$ expression in dorsal horns of SNL rats. This change directly reduces astrocyte activation in dorsal horns, which secrete TNF- $\alpha$ in the synaptic area, causing further glial activation and strengthening synaptic transmission.

\section{Conclusion}

Oral administration of lodenafil carbonate demonstrated antinociceptive effects in rodent models of inflammatory pain (formalin and carrageenan) and neuropathic pain (SNL), by activation of the NO/cGMP/PKG pathway and $\mathrm{K}^{+}$channel opening, ultimately leading to nociceptor hyperpolarization and decrease in activation of spinal synapses and glial cells. Inhibition of PDE5 by lodenafil carbonate may block neuroplastic changes in the spinal cord by acting peripherally on primary nociceptors, thus interfering with the process of pain. Therefore, lodenafil carbonate may prove useful to treat neuropathic pain and represents a new approach for management of chronic pain.

\section{Acknowledgments}

This research was funded by the Coordenação de Aperfeiçoamento de Pessoal de Nível Superior (CAPES), Conselho Nacional de Desenvolvimento Científico e Tecnológico (CNPq), Fundação Carlos Chagas Filho de Amparo à Pesquisa do Estado do Rio de Janeiro (FAPERJ), Cristália Produtos Químicos e Farmacêuticos, Ltda.

\section{Author Contributions}

All authors made a significant contribution to the work reported, whether that is in the conception, study design, execution, acquisition of data, analysis and interpretation, or in all these areas; took part in drafting, revising or critically reviewing the article; gave final approval of the version to be published; have agreed on the journal to which the article has been submitted and agree to be accountable for all aspects of the work.

\section{Disclosure}

Professor Gisele Zapata-Sudo report grants from CNPq, grants from FAPERJ, grants from Cristália Produtos Químicos e Farmacêuticos, outside the submitted work. The authors report no other conflicts of interest in this work.

\section{References}

1. Karsten A, Derouet H, Ziegler M, Eckert R. Involvement of cyclic nucleotides in renal artery smooth muscle relaxation. Urol Res. 2003;30(6):367-373. doi:10.1007/s00240-002-0281-2
2. de Nunes AKS, Rapôso C, Luna RLDA, Cruz-Höfling MAD, Peixoto CA. Sildenafil $\left(\right.$ Viagra $^{\circledR}$ ) down regulates cytokines and prevents demyelination in a cuprizone-induced MS mouse model. Cytokine. 2012;60(2):540-551. doi:10.1016/j.cyto.2012.06.011

3. Laxmi V, Gupta R, Bhattacharya SK, Ray A, Gulati K. Inhibitory effects of sildenafil and tadalafil on inflammation, oxidative stress and nitrosative stress in animal model of bronchial asthma. Pharmacol Reports. 2019;71 (3):517-521. doi:10.1016/j.pharep.2019.02.008

4. Li EA, Xi W, Han YS, Brozovich FV. Phosphodiesterase expression in the normal and failing heart. Arch Biochem Biophys. 2019; 662:160-168. doi:10.1016/j.abb.2018.12.013

5. Kotera J, Fujishige K, Omori K. Immunohistochemical Localization of cGMP-binding cGMP-specific Phosphodiesterase (PDE5) in Rat Tissues. J Histochem Cytochem. 2000;48(5):685-693. doi:10.1177/ 002215540004800512

6. Tsertsvadze A, Fink HA, Yazdi F, et al. Oral phosphodiesterase-5 inhibitors and hormonal treatments for erectile dysfunction: a systematic review and meta-analysis. Ann Intern Med. 2009;151 (9):650-661. doi:10.7326/0003-4819-151-9-200911030-00150

7. Galiè N, Barberà JA, Frost AE, et al. Initial use of ambrisentan plus tadalafil in pulmonary arterial hypertension. $N$ Engl J Med. 2015;373 (9):834-844. doi:10.1056/NEJMoa1413687

8. Ambriz-Tututi M, Velázquez-Zamora DA, Urquiza-Marín H, GranadosSoto V. Analysis of the mechanism underlying the peripheral antinociceptive action of sildenafil in the formalin test. Eur J Pharmacol. 2005;512 (2-3):121-127. doi:10.1016/j.ejphar.2005.01.055

9. Gediz Eİ, Nacitarhan C, Minareci E, Sadan G. Antinociceptive effect of vardenafil on carrageenan-induced hyperalgesia in rat: involvement of nitric oxide/cyclic guanosine monophosphate/calcium channels pathway. Iran J Pharm Res IJPR. 2015;14(4):1137-1143.

10. Otari KV, Upasani CD. Involvement of NO-cGMP pathway in anti-hyperalgesic effect of PDE5 inhibitor tadalafil in experimental hyperalgesia. Inflammopharmacology. 2015;23(4):187-194. doi:10. 1007/s10787-015-0240-5

11. Jain NK, Patil CS, Singh A, Kulkarni SK. Sildenafil-induced peripheral analgesia and activation of the nitric oxide-cyclic GMP pathway. Brain Res. 2001;909(1-2):170-178. doi:10.1016/S0006-8993(01)02673-7

12. Mehanna MM, Domiati S, Nakkash Chmaisse H, El Mallah A. Antinociceptive effect of tadalafil in various pain models: involvement of opioid receptors and nitric oxide cyclic GMP pathway. Toxicol Appl Pharmacol. 2018;352:170-175. doi:10.1016/j.taap.2018.05.013

13. Glina S, Fonseca GN, Bertero EB, et al. Efficacy and tolerability of lodenafil carbonate for oral therapy of erectile dysfunction: a Phase III clinical trial. J Sex Med. 2010;7(5):1928-1936. doi:10.1111/ j.1743-6109.2010.01711.x

14. Polonio IB, Acencio MMP, Pazetti R, et al. Lodenafil treatment in the monocrotaline model of pulmonary hypertension in rats. J Bras Pneumol. 2014;40(4):421-424. doi:10.1590/S1806-37132014000400010

15. Silva MDMCD, de Alencar AKND, de Silva JSD, et al. Therapeutic benefit of the association of lodenafil with mesenchymal stem cells on hypoxia-induced pulmonary hypertension in rats. Cells. 2020;9 (9):2120. doi:10.3390/cells9092120

16. Dubuisson D, Dennis SG. The formalin test: a quantitative study of the analgesic effects of morphine, meperidine, and brain stem stimulation in rats and cats. Pain. 1977;4(2):161-174. doi:10.1016/03043959(77)90130-0

17. Hunskaar S, Fasmer OB, Hole K. Formalin test in mice, a useful technique for evaluating mild analgesics. J Neurosci Methods. 1985;14(1):69-76. doi:10.1016/0165-0270(85)90116-5

18. Montes GC, Hammes N, da Rocha MD, et al. Treatment with adenosine receptor agonist ameliorates pain induced by acute and chronic inflammation. $J$ Pharmacol Exp Ther. 2016;358(2): 315-323. doi:10.1124/jpet.115.231241

19. Hargreaves K, Dubner R, Brown F, Flores C, Joris J. A new and sensitive method for measuring thermal nociception in cutaneous hyperalgesia. Pain. 1988;32(1):77-88. doi:10.1016/0304-3959(88)90026-7 
20. Lo R, JJ Selitto. A method for measurement of analgesic activity on inflamed tissue. Arch Int Pharmacodyn Ther. 1957;111(4):409-419.

21. Kim SH, Chung JM. An experimental model for peripheral neuropathy produced by segmental spinal nerve ligation in the rat. Pain. 1992;50(3):355-363. doi:10.1016/0304-3959(92)90041-9

22. Sudo RT, Hayashida K, Santos AN, et al. Novel agonist of $\alpha 4 \beta 2 *$ neuronal nicotinic receptor with antinociceptive efficacy in roden models of acute and chronic pain. J Pain Res. 2018;11:2453-2462. doi: $10.2147 /$ JPR.S169637

23. Wang WW, Wang WW, Mei X, et al. Crosstalk between spinal astrocytes and neurons in nerve injury-induced neuropathic pain. Hochman $\mathrm{S}$, ed. PLoS One. 2009;4(9):e6973. doi:10.1371/journal.pone.0006973

24. Schindelin J, Arganda-Carreras I, Frise E, et al. Fiji: an open-source platform for biological-image analysis. Nat Methods. 2012;9 (7):676-682. doi:10.1038/nmeth.2019

25. Li Z-H, Cui D, Qiu C-J, Song X-J. Cyclic nucleotide signaling in sensory neuron hyperexcitability and chronic pain after nerve injury. Neurobiol Pain (Cambridge, Mass). 2019;6:100028. doi:10.1016/j. ynpai.2019.100028

26. Hoheisel U, Unger T, Mense S. The possible role of the NO-cGMP pathway in nociception: different spinal and supraspinal action of enzyme blockers on rat dorsal horn neurones. Pain. 2005;117 (3):358-367. doi:10.1016/j.pain.2005.06.023

27. Cunha FQ, Teixeira MM, Ferreira SH. Pharmacological modulation of secondary mediator systems-cyclic AMP and cyclic GMP-on inflammatory hyperalgesia. Br J Pharmacol. 1999;127(3):671-678. doi:10.1038/sj.bjp.0702601

28. Cury Y, Picolo G, Gutierrez VP, Ferreira SH. Pain and analgesia: the dual effect of nitric oxide in the nociceptive system. Nitric Oxide. 2011;25(3):243-254. doi:10.1016/j.niox.2011.06.004

29. Freire MAM, Guimarães JS, Leal WG, Pereira A. Pain modulation by nitric oxide in the spinal cord. Front Neurosci. 2009;3(2):175-181. doi:10.3389/neuro.01.024.2009

30. Schmidtko A, Tegeder I, No GG. NO, no pain? The role of nitric oxide and cGMP in spinal pain processing. Trends Neurosci. 2009;32 (6):339-346. doi:10.1016/j.tins.2009.01.010

31. Patil CS, Padi SV, Singh VP, Kulkarni SK. Sildenafil induces hyperalgesia via activation of the NO-cGMP pathway in the rat neuropathic pain model. Inflammopharmacology. 2006;14(1-2):22-27. doi:10.1007/s10787-006-1511-y

32. Dos santos GG, Dias EV, Teixeira JM, et al. The analgesic effect of dipyrone in peripheral tissue involves two different mechanisms: neuronal KATP channel opening and CB1 receptor activation. Eur J Pharmacol. 2014;741:124-131. doi:10.1016/j.ejphar.2014.07.019.

33. Cunha TM, Roman-Campos D, Lotufo CM, et al. Morphine peripheral analgesia depends on activation of the PI3K/AKT/nNOS/NO/ KATP signaling pathway. Proc Natl Acad Sci. 2010;107 (9):4442-4447. doi:10.1073/pnas.0914733107

34. Nordgaard JC, Kruse LS, Møller M, Kruuse C. Phosphodiesterases 3 and 5 express activity in the trigeminal ganglion and co-localize with calcitonin gene-related peptide. Cephalalgia. 2014;34(7):503-513. doi:10.1177/0333102413515345

35. de Vente J, Markerink-van Ittersum M, Vles JSHSH. The role of phosphodiesterase isoforms 2,5 , and 9 in the regulation of NO-dependent and NO-independent cGMP production in the rat cervical spinal cord. J Chem Neuroanat. 2006;31(4):275-303. doi:10.1016/j.jchemneu.2006.02.006

36. Wang L, Chopp M, Szalad A, et al. Tadalafil promotes the recovery of peripheral neuropathy in Type II diabetic mice. Caporali A, ed. PLoS One. 2016;11(7):e0159665. doi:10.1371/journal.pone.0159665
37. Kaur M, Singh A, Kumar B, et al. Protective effect of co-administration of curcumin and sildenafil in alcohol induced neuropathy in rats. Eur J Pharmacol. 2017;805:58-66. doi:10.1016/j. ejphar.2017.03.012

38. Patil CS, Singh VP, Kulkarni SK. Peripheral and central activation of nitric oxide-cyclic GMP pathway by sildenafil. Inflammopharmacology. 2005;13(5-6):467-478. doi:10.1163/156856005774649359

39. Mixcoatl-Zecuatl T, Aguirre-Bañuelos P, Granados-Soto V. Sildenafil produces antinociception and increases morphine antinociception in the formalin test. Eur J Pharmacol. 2000;400(1):81-87. doi:10.1016/ s0014-2999(00)00361-7

40. Yoon MH, Park KD, Lee HG, et al. Additive antinociception between intrathecal sildenafil and morphine in the rat formalin test. $J$ Korean Med Sci. 2008;23(6):1033. doi:10.3346/jkms.2008.23.6.1033

41. Tanabe M, Nagatani Y, Saitoh K, Takasu K, Ono H. Pharmacological assessments of nitric oxide synthase isoforms and downstream diversity of NO signaling in the maintenance of thermal and mechanical hypersensitivity after peripheral nerve injury in mice. Neuropharmacology. 2009;56 (3):702-708. doi:10.1016/j.neuropharm.2008.12.003

42. Millan MJ. Descending control of pain. Prog Neurobiol. 2002;66 (6):355-474. doi:10.1016/s0301-0082(02)00009-6

43. Spiller F, Oliveira Formiga R, Fernandes da Silva Coimbra J, et al. Targeting nitric oxide as a key modulator of sepsis, arthritis and pain. Nitric Oxide Biol Chem. 2019;89:32-40. doi:10.1016/j.niox.2019.04.011

44. Melkani I, Kumar B, Panchal S, et al. Comparison of sildenafil, fluoxetine and its co-administration against chronic constriction injury induced neuropathic pain in rats: an influential additive effect. Neurol Res. 2019;41 (10):875-882. doi:10.1080/01616412.2019.1630091

45. Morlion B, Coluzzi F, Aldington D, et al. Pain chronification: what should a non-pain medicine specialist know? Curr Med Res Opin. 2018;34(7):1169-1178. doi:10.1080/03007995.2018.1449738

46. Terayama R, Yamamoto Y, Kishimoto N, et al. Differential changes in neuronal excitability in the spinal dorsal horn after spinal nerve ligation in rats. Neurochem Res. 2016;41(11):2880-2889. doi:10. 1007/s11064-016-2003-0

47. Wang J, Zeng L, Zhou Q, et al. L6 spinal nerve ligation produces prolonged development of mechanical allodynia and gradual increase of GFAP on ipsilateral dorsal horn. Acta Neurochir (Wien). 2013;155 (5):935-940. doi:10.1007/s00701-012-1616-6

48. Jin S-X, Zhuang Z-Y, Woolf CJ, Ji -R-R. p38 mitogen-activated protein kinase is activated after a spinal nerve ligation in spinal cord microglia and dorsal root ganglion neurons and contributes to the generation of neuropathic pain. $J$ Neurosci. 2003;23(10): 4017-4022. doi:10.1523/JNEUROSCI.23-10-04017.2003

49. Mika J, Zychowska M, Popiolek-Barczyk K, Rojewska E, Przewlocka B. Importance of glial activation in neuropathic pain. Eur J Pharmacol. 2013;716(1-3):106-119. doi:10.1016/j.ejphar.2013.01.072

50. Raghavendra V, Tanga F, DeLeo JA. Inhibition of microglial activation attenuates the development but not existing hypersensitivity in a rat model of neuropathy. J Pharmacol Exp Ther. 2003;306 (2):624-630. doi:10.1124/jpet.103.052407

51. Gruber-Schoffnegger D, Drdla-Schutting R, Hönigsperger C, Wunderbaldinger G, Gassner M, Sandkühler J. Induction of thermal hyperalgesia and synaptic long-term potentiation in the spinal cord lamina I by TNF- $\alpha$ and IL- $1 \beta$ is mediated by glial cells. J Neurosci. 2013;33(15):6540-6551. doi:10.1523/JNEUROSCI.5087-12.2013

52. Olmos G, Lladó J. Tumor necrosis factor alpha: a link between neuroinflammation and excitotoxicity. Mediators Inflamm. 2014; 2014:1-12. doi:10.1155/2014/861231 


\section{Publish your work in this journal}

The Journal of Pain Research is an international, peer reviewed, open access, online journal that welcomes laboratory and clinical findings in the fields of pain research and the prevention and management of pain. Original research, reviews, symposium reports, hypothesis formation and commentaries are all considered for publication. The manuscript management system is completely online and includes a very quick and fair peer-review system, which is all easy to use. Visit http:// www.dovepress.com/testimonials.php to read real quotes from published authors. 